\title{
Fentanyl Sublingual Spray
}

National Cancer Institute

\section{Source}

National Cancer Institute. Fentanyl Sublingual Spray. NCI Thesaurus. Code C74029.

A sublingual preparation of a short-acting, synthetic anilidopiperidine opioid with analgesic activity. After rapid sublingual transmucosal absorption, the active ing redient fentanyl selectively binds to and activates mu-opioid receptors in the central nervous system (CNS), mimicking the effects of endogenous opiates. 